\title{
ARTICLES
}

\section{Assessment of the occurrence and threats to Hooded Vultures Necrosyrtes monachus in western Kenyan towns}

\author{
Martin Odino ${ }^{1,2}$, Titus Imboma ${ }^{1,2}$ and Darcy L. Ogada ${ }^{1,2,3 *}$
}

\author{
${ }^{1}$ Raptor Working Group of Nature Kenya, Box 44486, 00100-Nairobi, Kenya \\ ${ }^{2}$ National Museums of Kenya, Ornithology Section, Box 40658, 00100-Nairobi, Kenya \\ ${ }^{3}$ The Peregrine Fund, 5668 West Flying Hawk Lane, Boise, Idaho, 83709, USA
}

*Corresponding author: darcyogada@yahoo.com

\section{Summary}

The Hooded Vulture Necrosyrtes monachus is endemic to Africa and has recently been uplisted to Endangered on the IUCN Red List. Populations of Hooded Vulture in Kenya have declined significantly in recent decades and urban populations exist primarily in western Kenya towns where they typically forage at slaughterhouses and dumpsites. We surveyed seven western Kenyan towns and one neighbouring Ugandan market centre to assess the occurrence and threats to this species using opportunistic observations and interviews with employees at slaughterhouses and dumpsite facilities. We observed 23 Hooded Vultures, 20 in Bungoma Town and 3 in Busia-Uganda. Scavenging vultures were only observed at open-air slaughterhouses or dumpsites. We conducted 34 interviews at 14 facilities of which 23 interviews from six facilities were determined to be of good quality and used for subsequent analyses. At four of the facilities employees confirmed that Hooded Vulture numbers had declined and two respondents indicated declines had occurred from the year 2000 onwards. Possible reasons for declines mentioned by respondents were the introduction of closed-system of slaughterhouses, poisoning of stray dogs, cutting of roost trees, and increased competition for food. There was little evidence of exploitation of the birds for witchcraft or for food. 


\section{Introduction}

The Hooded Vulture is an African endemic that was recently uplisted to Endangered on the IUCN Red List (Birdlife International 2013). The uplisting was due to its rapid decline throughout most of its range and reports suggest its decline has been caused by overhunting, persecution and indiscriminate poisoning, as well as improvements in slaughterhouse hygiene and rubbish disposal where the species previously fed (Ogada \& Buij 2011).

Hooded Vultures occupy a wide range of habitats including arid country, towns, grassland, cultivation and coastal areas (Mundy et al. 1992). It is a species with urban populations that live in close association with humans very common in West and parts of East Africa, while populations in Tanzania and further south are primarily found in savannahs far from human disturbance (Mundy et al. 1992). Wright (1960) described the Hooded Vulture as the commonest vulture within the Nairobi, Tsavo and Serengeti National Parks. In Kenya the species was previously widespread in most national parks, game reserves and in many towns (Zimmerman et al. 1996).
Recent evidence suggests that the species has declined substantially in Kenya and Uganda (Ssemmanda \& Pomeroy 2010; Ogada \& Buij 2011; Virani et al. 2011). In Kenya although it is still present in most national parks and game reserves, and around pastoral settlements in the north, the only urban populations are in western Kenya, along the lower Tana River, and presumably still in Moyale town despite no recent ornithological surveys (Zimmerman et al. 1996; S. Thomsett, pers. comm.; D. Ogada, unpub. data). A recent study by Virani et al. (2011) reported Hooded Vulture declines of $62 \%$ in and around the Masai Mara National Reserve from 1976 to 2005. Similarly, annual raptor road surveys since 2010 have only recorded three Hooded Vultures over $7200 \mathrm{kms}$ (Ogada et al. 2010, D. Ogada, unpub. data). However, a recent expedition to northern Kenya recorded pairs of Hooded Vultures at most small settlements that were slaughtering camels around the Chalbi Desert (F. Reid pers. comm.).

This study assessed the occurrence of Hooded Vultures in western Kenyan towns, specifically at slaughterhouses and dumpsites. The study also sought to determine the reasons for the decline in Hooded 
Vultures in western Kenya by interviewing local people about possible cases of poisoning, or exploitation of Hooded Vultures for food or use in witchcraft.

\section{Methods}

\section{Study area}

The study was undertaken from 23-31 May 2012 during the rainy season in western Kenyan towns and market centres (Table 1). We included the Ugandan side of Busia town because residents on the Kenyan side suggested that we may find more Hooded Vultures on the Ugandan side. We visited a total of eight towns and market centres and at each location we surveyed one or more of the relevant facilities where Hooded Vultures would be expected, including slaughterhouses, butcheries, hospital dumpsites, and sewage ponds (Table 1).

\section{Data collection}

Fieldwork was conducted by MO and TI and consisted of opportunistic observations of Hooded Vultures at facilities where the birds were historically known, and interviews with facility personnel and at market places.

All observations of Hooded Vultures were recorded including number of individuals, age class, and behavioural aspects including flying, perching, foraging and interactions with other species. Age classes were either adult or juvenile. Juvenile birds were distinguished from adults based upon the dark brown feathers on the back of the head and lack of red facial pigmentation (Zimmerman et al. 1996). To avoid double counting birds, we recorded the maximum number of vultures seen at any one time per site. For example, if we observed two birds at the slaughterhouse and three at the hospital dumpsite in Bungoma we recorded a total of five vultures for Bungoma. Because the towns were small, movement of vultures between sites in a single town would likely have been noticed. For multiple day observations, we considered the highest number of birds seen and counted at each site on a single day. Evident threats to Hooded Vultures that were not addressed during interviews were also recorded. Interviewers approached personnel at slaughterhouses, butcheries, hospitals and sewage works, and introduced themselves before explaining the survey and its purpose. 
Table 1. Locations and respective facilities visited for surveys of Hooded Vultures in western Kenyan towns.

\begin{tabular}{|c|c|c|}
\hline $\begin{array}{l}\text { Town/market } \\
\text { centre }\end{array}$ & GPS location & Facility \\
\hline Busia-Kenya & $\begin{array}{l}28^{\prime} 18.8^{\prime \prime} \mathrm{N} \\
3404^{\prime} 54.6 " \mathrm{E}\end{array}$ & Municipal council slaughterhouse \\
\hline Busia-Uganda & $\begin{array}{ll}28^{\prime} 18.8^{\prime \prime} & \mathrm{N} \\
3404^{\prime} 54.6^{\prime \prime} & \mathrm{E}\end{array}$ & Lufura slaughterhouse \\
\hline Malaba & $\begin{array}{l}37^{\prime} 00.6^{\prime \prime} \mathrm{N} \\
3420^{\prime} 38.5^{\prime \prime} \mathrm{E}\end{array}$ & $\begin{array}{l}\text { Municipal council slaughterhouse, } \\
\text { sewage ponds, dumpsite }\end{array}$ \\
\hline $\begin{array}{l}\text { Awata/Kocholi } \\
\text { a }\end{array}$ & $\begin{array}{l}\text { Same as } \\
\text { Malaba }\end{array}$ & Slaughterhouse \\
\hline Bungoma & $\begin{array}{l}33^{\prime} 39.9^{\prime \prime} \mathrm{N} \\
3433^{\prime} 50.7^{\prime \prime} \mathrm{E}\end{array}$ & $\begin{array}{l}\text { Municipal council slaughterhouse, } \\
\text { district hospital, sewage ponds }\end{array}$ \\
\hline Webuye & $\begin{array}{l}35^{\prime} 13.4^{\prime \prime} \mathrm{N} \\
3446^{\prime} 41.1^{\prime \prime} \mathrm{E}\end{array}$ & Municipal council slaughterhouse \\
\hline Kitale & Not recorded & Municipal council slaughterhouse \\
\hline Kakamega & $\begin{array}{l}16^{\prime} 49.0^{\prime \prime} \mathrm{N} \\
3445^{\prime} 24.2^{\prime \prime} \mathrm{E}\end{array}$ & $\begin{array}{l}\text { Golf Hotel, town slaughterhouse, district } \\
\text { hospital }\end{array}$ \\
\hline
\end{tabular}

We conducted 1-4 surveys per facility and rated the quality of the surveys at each facility as either good or poor depending on the amount and quality of information obtained. Examples of responses that were rated as 'good' included those where the interviewees demonstrated their knowledge of the bird through accurate description of its appearance, behaviour and occurrence. Poor responses were those where interviewees obviously did not know the bird, or knew little of its occurrence at the site. We approached personnel at the facilities and conducted an open-ended questionand-answer-type survey, subsequently 
referred to as the 'facilities' survey (Appendix 1). Interviews were conducted in Kiswahili and/or Kiluhya. Most interviews were answered by one respondent. However, when there was an interested audience that was willing to share information one representative provided responses for the group. If there was disagreement amongst the group, a final response was given after group discussion and consent. Facility personnel were asked to identify Hooded Vultures after being shown images of a Marabou Stork and a Hooded Vulture. They were also asked where the birds were found at the facility. If they were unable to correctly identify the bird or indicate where it could be found the interview concluded.

Information on the possible exploitation of Hooded Vultures for food and/or as a fetish was solicited using a separate survey form, subsequently referred to as the 'fetish' survey (Appendix 2). We targeted the elderly (50+ years) because they were perceived to be more frank and knowledgeable on the traditional practice of witchcraft and fetishes. The elderly take pride in traditions while many young people ( $<40$ years old) are mostly indifferent to traditional practices because of the widespread adoption of western cultural practices after the postcolonial period. A few initial surveys were administered at market places in Busia and Bungoma towns, but the respondents informed us that they were not aware of the use of the birds in witchcraft. Subsequently the survey was administered at the same facilities (slaughterhouse, butchery, hospital, and sewage works) as the facility survey since these places may be the harvesting areas for the birds if they were being used for witchcraft. There is unlikely to be any conflict of interest in conducting the fetish surveys at the facilities because it is unlikely that facilities personnel are substantially benefitting from any potential trade in vulture fetishes. We were also unable to administer the fetish survey at the markets because most markets only operated on a set day of the week and often this did not coincide with our visits.

\section{Results}

We completed a total of 34 interviews, comprising 23 facilities surveys and 11 fetish surveys. Facility surveys were conducted at 14 facilities in seven towns in western Kenya and one town in eastern Uganda. At six facilities we obtained 
good quality information that generally included long-term knowledge of Hooded Vultures at the facility, suspected causes of the birds' disappearance, and general observations about the birds (Table 2). At eight facilities we obtained poor quality information either because the facilities were nonoperational, not conducive to supporting Hooded Vultures, or those being interviewed had no or little knowledge of the birds (Table 2). We restrict our further analyses to the facilities that generated good quality information based upon 14 interviews.

All of the slaughterhouses visited $(\mathrm{n}=5)$ were of a modern-type in that animals were slaughtered inside a closed facility, as opposed to in the open air. The most notable difference between slaughterhouses was whether the disposal of effluent was open-air $(\mathrm{n}=3)$ or in closed underground storage tanks $(\mathrm{n}=2)$. We only observed 23 Hooded Vultures at two slaughterhouses where effluent was disposed on open ground and at one open-air dumpsite (Table 2).

At four of the six facilities there were reports of large declines in the number of Hooded Vultures observed with two respondents noting that the declines occurred as recently as the early 2000s (Table 2). Before then, Hooded Vultures were frequent and regular, but most respondents noted that currently Hooded Vultures were only present at their facilities during the dry season (Table 2).

Evidence for direct competition for food was noted between Hooded Vultures and Marabou Storks, Pied Crows, dogs and humans (Table 2). Further evidence of indirect competition for food with humans was also noted (Table 2).

Possible reasons stated for the decline in Hooded Vulture numbers included the change from open-air slaughterhouses, poisoning of dogs, and felling of trees that the vultures use for roosting (Table 2).

We did not detect or witness trading of any sort in the Hooded Vulture or the bird's parts during the survey. Only one out of the 11 administered fetish questionnaires suggested exploiting vultures' parts for undisclosed reasons. According to the respondent in Busia TownUganda there were irregular times when word would go around that vultures were required. An undisclosed, but large amount, would then be paid for successfully obtaining vultures/parts.

In addition, two respondents at Kocholia and Bungoma, respectively 
informed us that the birds were hated and regarded as filthy, indicating a very negative perception.

\section{Discussion}

Hooded Vultures were known by at least one respondent in all the eight surveyed locations. The species is further known by vernacular names amongst the various communities in Western Kenya including, Atarukot in Teso and Engosya in Luhya. This supports the fact that the species occurred throughout the surveyed range. Hooded Vultures were however only observed at two out of the eight surveyed locations (BusiaUganda and Bungoma). However, these results should be interpreted with caution as most people interviewed acknowledged that the birds were more abundant in the dry season. Many of the respondents directed us to other locations in western Kenya and Uganda where they believed the Hooded Vultures could be seen. However, upon visiting many of the locations mentioned in Kenya including the Golf Hotel in Kakamega town and Busia Municipal slaughterhouse in Busia-Kenya, we typically did not find any Hooded Vultures. While this may be attributable to our visit during the rainy season and to the weekly rather than daily activity of most individual facilities, it may also be indicative of what we suspect to be recent declines of this species within the region. Hooded Vultures were only found at slaughterhouses and dumpsites where waste was disposed on open ground. It is not surprising that as modern closed slaughterhouses with underground waste disposal are erected there may be negative effects on urban Hooded Vulture populations, especially since urban Hooded Vultures are more numerous at slaughterhouses than at dumpsites due to their preference for foraging on animal tissues and other soft parts (Pomeroy 1975, Mundy 1976). As slaughterhouses are modernized, animal waste available to Hooded Vultures is much reduced, if not eliminated altogether.

Competition between Hooded Vultures and other species was observed at the two sites where the species was encountered. At Lufura slaughterhouse Hooded Vultures were chased by Marabou Storks and mobbed by Pied Crows as they scavenged. According to Pomeroy (1975) competition between six species of scavenging birds in Kampala was rare, but amongst ground-feeding species, Marabou 
Storks were dominant over Hooded Vultures, which in turn were dominant over Pied Crows. Perhaps due to their low numbers $(n=3)$ the Hooded Vultures we observed were dominated by Pied Crows. In addition to competition from other avian scavengers, Hooded Vultures in our study were likely negatively affected by direct and indirect competition from human scavengers. In BusiaUganda young boys collected a discarded cow foetus and chased the vultures away. An increase in competition between Hooded Vultures and other scavengers in Kampala, namely Marabou Storks and humans has also been mentioned (D. Pomeroy, pers. comm.). Of all the urban scavengers, Hooded Vultures are the only obligate scavengers and therefore they may be disproportionally affected by increasing competition from facultative scavengers such as Marabou Storks, Pied Crows, Black Kites and humans.

In addition to food supply, the presence of roosting trees and secure compounds may play a role in attracting Hooded Vultures. Bungoma District Hospital had numerous mature trees within its compound, forming an extensive closed canopy in some places. A guest house in Bungoma had tall eucalyptus trees in which a pair of vultures roosted. The felling of roost trees has been noted as a possible reason for the decline of Hooded Vultures in Kampala (Ssemmanda \& Pomeroy 2010). The hospital dumpsite was remotely located and fenced off, which likely secured birds from human interference. Although urban Hooded Vultures in West Africa co-exist in close proximity to people, urban populations in Kenya are more wary and we never saw the birds within $5 \mathrm{~m}$ of people.

Incidental poisoning of Hooded Vultures was mentioned at three of the six facilities with good quality information. However, it is unclear to what extent this may have affected vulture populations as there was no information on the possible number of birds poisoned. At all the facilities where poisoning had occurred the intended target was stray and/or rabid dogs. The poisoning of dogs is a widespread problem in Africa, but little information is formally reported (Abebe 2013, D. Pomeroy, pers. comm., J. Wolstencroft, pers. comm). It is largely through personal contacts and raptor list-servs that this information is disseminated and therefore it is likely underestimated (D. Ogada, pers. obs.). 
We uncovered little evidence that there is widespread use of Hooded Vultures for witchcraft or for consumption as food, as is reported in West Africa (Akagu \& Adeleke 2012, Gbogbo \& Awotwe-Pratt, 2008, Rondeau \& Thiollay 2004, Nikolaus 2001). Generally the birds were despised because of negative attitudes towards them such as looking unclean and ugly.

Broadly, this study found negative attitudes and ignorance as a threat and a potential driver of decimation of this species of concern. Although well-known by locals in the range, many people interviewed were not concerned or aware of the plight of the birds. For instance, responses from Busia revealed that many could not recall when they last saw large flocks of the species; many respondents could also hardly remember how many birds still came to their locale or facility. One respondent at Lufura slaughterhouse convinced us to return the next day where we would see up to 200 birds at the slaughterhouse, being a slaughter day, but we saw only three birds. Many respondents also cited Kakamega Town and the Golf Hotel as a stronghold for the Hooded Vulture, but none were observed or reported by the hotel's long-serving employees. While this is also indicative that information obtained through interviews can be unreliable, the sites mentioned have a long history amongst the Kenyan ornithological community of supporting Hooded Vultures (Ogada \& Buij 2011, D. Fisher unpub. data). Therefore, we suspect the information obtained is more likely a result of the decline of Hooded Vultures at these sites, which concurs with limited historical data from the western Kenya region (D. Fisher unpub. data).

It is therefore a worrying trend that locals are not conscious of the threats to this biodiversity component living in their midst. A majority of respondents acknowledged that the species' numbers had declined but struggled to recall when they last saw the species and how many there were. Besides, no respondent had encountered a dead Hooded Vulture. This is an indication of how latent and yet devastating the threats are to this species with the potential final effect being extinction of the local populations of this species.

\section{Recommendations}

- The areas suggested by respondents as likely strongholds of Hooded Vultures should be surveyed 
to assess the status of the species at these sites. These include Machabus, Kimilili and Adungosi. Consideration should also be given to remote sites still practising the open slaughterhouse system.

- The sites surveyed during this study which were pointed out by respondents as prolific for the species, but where vultures were not observed, should be closely monitored and re-surveyed to establish the actual status of the Hooded Vulture at the sites. These include Kakamega District Hospital and the Golf Hotel.

- Opportunities should be looked into to modify the closed system of abattoirs so that the design continues to facilitate the existence of important scavengers including Hooded Vultures.

- A conservation awareness campaign should be conducted in the species' human settlement range to educate locals on the Hooded Vulture, their role, and plight.

- A follow-up survey should be conducted in the western Kenyan towns during the dry season to ascertain the actual status of the species during this time when respondents revealed the species is most abundant in the region.

\section{Acknowledgments}

The authors thank The Birdfair/RSPB Research Fund for Endangered Birds for supporting this research. We also thank those who participated in our interviews.

\section{References}

Abebe, Y.D. 2013. Mass dog poisoning operation in Addis Ababa can have severe repercussions on vulture populations. Vulture News 64: 74-76.

Akagu, R. and Adeleke, A. 2012. Current status and threats facing the Nigeria vultures. Submitted to the pan-African Vulture Summit, Masai Mara, Kenya 16-20 April 2012. Nigerian Conservation Foundation.

BirdLife International 2013. Necrosyrtes monachus. In: IUCN 2013. IUCN Red List of Threatened Species. Version 2013.1. 〈www.iucnredlist.org>.

Downloaded on 14 April 2013. 
Gbogbo, F. \& Awaotwe-Pratt, V. P. 2008. Waste management and Hooded Vultures on the Legon Campus of the University of Ghana in Accra, Ghana, West Africa. Vulture News 58: 16-22.

Mundy, P. 1976. The two faces of the Hooded Vulture. Bokmakierie 28: 84-86.

Mundy, P., Butchart, D., Ledger, J. \& Piper, S. 1992. The vultures of Africa. London: Academic Press.

Nikolaus, G. 2001. Bird exploitation for traditional medicine in Nigeria. Malimbus 23: 45-55.

Ogada, D. L. \& Buij, R. 2011. Large declines of the Hooded Vulture Necrosyrtes monachus across its African range. Ostrich 82: 101-113.

Ogada, D.L, Thomsett, S., Virani, M.Z., Kendall, C. \& Odino, M. 2010. Raptor road counts in Kenya: with emphasis on vultures. Unpublished report to the Royal Society for the Protection of Birds, Sandy, Bedfordshire, UK.

Pomeroy, D. 1975. Birds as scavengers of refuse in Ugansa. Ibis 117: 69-81.

Ssemmanda, R. \& Pomeroy, D. 2010. Scavenging birds of Kampala: 19732009. Scopus 30: 26-31.

Virani, M. Z., Kendall, C., Njoroge, P. \& Thomsett, S. 2011. Major declines in the abundance of vultures and other scavenging raptors in and around the Masai Mara ecosystem, Kenya. Biological Conservation 144: 746-752.

Wright, B.S. 1960. Predation on big game in East Africa. The Journal of Wildlife Management 24: 1-15.

Zimmerman, D.A., Turner, D.A. \& Pearson, D.J. 1996. Birds of Kenya and Northern Tanzania. London: Christopher Helm. 
Table 2. Results of 14 facility surveys and opportunistic observations of Hooded Vultures in seven towns in western Kenya and one town in eastern Uganda.

\begin{tabular}{|c|c|c|c|c|c|c|c|c|c|c|c|}
\hline Location & $\begin{array}{l}\text { Type of } \\
\text { facility }\end{array}$ & $\begin{array}{l}\text { Quality of } \\
\text { survey }\end{array}$ & $\begin{array}{l}\text { Number of } \\
\text { HVs } \\
\text { observed }\end{array}$ & $\begin{array}{l}\text { Animal } \\
\text { waste } \\
\text { visible }\end{array}$ & $\begin{array}{l}\text { Effluent } \\
\text { disposal } \\
\text { (open/closed) }\end{array}$ & Status of HV & $\begin{array}{l}\text { Evidence of } \\
\text { competition }\end{array}$ & $\begin{array}{l}\text { Evidence of } \\
\text { decline }\end{array}$ & $\begin{array}{l}\text { Possible } \\
\text { reasons for } \\
\text { decline }\end{array}$ & $\begin{array}{l}\text { Evidence of } \\
\text { seasonality }\end{array}$ & Comments \\
\hline $\begin{array}{l}\text { Busia- } \\
\text { Kenya }\end{array}$ & $\begin{array}{l}\text { Slaughter } \\
\text { house }\end{array}$ & Good & 0 & No & Closed & $\begin{array}{l}\text { One respondent } \\
\text { had seen } \mathrm{HV} \text { in } \\
\text { the area and had } \\
\text { seen } 40 \text { at one } \\
\text { time }\end{array}$ & $\mathrm{n} / \mathrm{a}$ & $\begin{array}{l}\text { HV numbers } \\
\text { reported not } \\
\text { to have } \\
\text { declined }\end{array}$ & $\mathrm{n} / \mathrm{a}$ & $\begin{array}{l}\text { More } \\
\text { common in } \\
\text { dry season }\end{array}$ & $\begin{array}{l}\text { Respondent said more } \\
\text { birds at Lufura } \\
\text { slaughterhouse in } \\
\text { Busia-Uganda and at } \\
\text { Golf Hotel where over } \\
50 \text { could be seen. Also } \\
\text { many HV in Iganga } \\
\text { Town, Uganda. }\end{array}$ \\
\hline $\begin{array}{l}\text { Busia- } \\
\text { Uganda }\end{array}$ & $\begin{array}{l}\text { Lufura } \\
\text { slaughter } \\
\text { house }\end{array}$ & Good & 3 & Yes & Open ground & $\begin{array}{l}\text { HV observed } \\
\text { foraging on } \\
\text { digestive } \\
\text { contents of dead } \\
\text { livestock that } \\
\text { was scattered on } \\
\text { open ground. }\end{array}$ & $\begin{array}{l}\text { HVs mobbed by } \\
\text { Pied Crows and } \\
\text { chased by } \\
\text { Marabou Storks. } \\
\text { Four humans and } \\
\text { two dogs also } \\
\text { scavenging at site. } \\
\text { Children removed } \\
\text { calf foetus on } \\
\text { which HVs were } \\
\text { attempting to feed. }\end{array}$ & $\begin{array}{l}\text { Reported } \\
\text { that up to } \\
300 \mathrm{HVs} \\
\text { used to visit } \\
\text { slaughterhou } \\
\text { se but in } \\
\text { recent times } \\
\text { only 2-4 } \\
\text { would come. } \\
\text { No one could } \\
\text { recall when } \\
\text { the declines } \\
\text { began }\end{array}$ & $\begin{array}{l}\text { Unknown, no } \\
\text { poisoning of } \\
\text { pests at the } \\
\text { facility }\end{array}$ & $\begin{array}{l}\text { Not } \\
\text { mentioned }\end{array}$ & $\begin{array}{l}\text { Respondent } \\
\text { recommended lganga } \\
\text { Town, Uganda as } \\
\text { having many HVs. }\end{array}$ \\
\hline
\end{tabular}


Table 2 - continued.

\begin{tabular}{|c|c|c|c|c|c|c|c|c|c|c|c|}
\hline Location & $\begin{array}{l}\text { Type of } \\
\text { facility }\end{array}$ & $\begin{array}{l}\text { Quality of } \\
\text { survey }\end{array}$ & $\begin{array}{l}\text { Number of } \\
\text { HVs } \\
\text { observed }\end{array}$ & $\begin{array}{l}\text { Animal } \\
\text { waste } \\
\text { visible }\end{array}$ & $\begin{array}{l}\text { Effluent } \\
\text { disposal } \\
\text { (open/closed) }\end{array}$ & $\begin{array}{l}\text { Status of } \\
\text { HV }\end{array}$ & $\begin{array}{l}\text { Evidence of } \\
\text { competition }\end{array}$ & $\begin{array}{l}\text { Evidence of } \\
\text { decline }\end{array}$ & $\begin{array}{l}\text { Possible } \\
\text { reasons for } \\
\text { decline }\end{array}$ & $\begin{array}{l}\text { Evidence of } \\
\text { seasonality }\end{array}$ & Comments \\
\hline $\begin{array}{l}\text { Kocholia } \\
\text { and Awata }\end{array}$ & $\begin{array}{l}\text { Slaughter } \\
\text { house }\end{array}$ & Good & 0 & Yes & Open & $\begin{array}{l}\text { Only 1-2 } \\
\text { HVs } \\
\text { observed } \\
\text { foraging in } \\
\text { mornings } \\
\text { after human } \\
\text { activity had } \\
\text { reduced }\end{array}$ & $\begin{array}{l}\text { HVs used to } \\
\text { feed on } \\
\text { clotted blood } \\
\text { when it was } \\
\text { disposed of } \\
\text { but now the } \\
\text { commodity is } \\
\text { in demand } \\
\text { by pig } \\
\text { farmers }\end{array}$ & $\begin{array}{l}\text { HV numbers } \\
\text { notably declined } \\
\text { during } 2000 \text { s. One } \\
\text { responded recalled } \\
\text { seeing last large } \\
\text { flocks in } 2004 . \\
\text { Used to see flocks } \\
\text { of } 50-60 \text { HVs when } \\
\text { slaughter house } \\
\text { was still open air } \\
\text { type. Eldest } \\
\text { respondent (60+ } \\
\text { yrs) recounted that } \\
\text { HVs were } \\
\text { abundant in 1970s- } \\
\text { 1990s }\end{array}$ & $\begin{array}{l}\text { All respondents } \\
\text { said HVs were } \\
\text { more common } \\
\text { and would feed } \\
\text { on meat } \\
\text { remains when } \\
\text { slaughter house } \\
\text { was open-air } \\
\text { type. No } \\
\text { poisoning of } \\
\text { pests at } \\
\text { Kocholia, but at } \\
\text { Awata there } \\
\text { used to be } \\
\text { accidental } \\
\text { poisoning by } \\
\text { Furadan } \\
\text { targeted at rabid } \\
\text { dogs as } \\
\text { carcasses were } \\
\text { not disposed of }\end{array}$ & $\begin{array}{l}\text { More } \\
\text { common in } \\
\text { dry season }\end{array}$ & $\begin{array}{l}\text { Reported that } 40-50 \\
\text { birds were seen in } \\
2011 \text { at Kakamega } \\
\text { Hospital. HVs were } \\
\text { more likely to be found } \\
\text { at Machabus, Lukolis } \\
\text { and Adungosi, Uganda }\end{array}$ \\
\hline
\end{tabular}


Table 2 - continued.

\begin{tabular}{|c|c|c|c|c|c|c|c|c|c|c|c|}
\hline Location & $\begin{array}{l}\text { Type of } \\
\text { facility }\end{array}$ & $\begin{array}{l}\text { Quality of } \\
\text { survey }\end{array}$ & $\begin{array}{l}\text { Number } \\
\text { of HVs } \\
\text { observed }\end{array}$ & $\begin{array}{l}\text { Animal } \\
\text { waste } \\
\text { visible }\end{array}$ & $\begin{array}{l}\text { Effluent } \\
\text { disposal } \\
\text { (open/closed) }\end{array}$ & Status of HV & $\begin{array}{l}\text { Evidence of } \\
\text { competition }\end{array}$ & $\begin{array}{l}\text { Evidence of } \\
\text { decline }\end{array}$ & $\begin{array}{l}\text { Possible } \\
\text { reasons for } \\
\text { decline }\end{array}$ & $\begin{array}{l}\text { Evidence of } \\
\text { seasonality }\end{array}$ & Comments \\
\hline Bungoma & $\begin{array}{l}\text { Slaughter } \\
\text { house }\end{array}$ & Good & 5 & Yes & Open & $\begin{array}{l}\text { Two long-term } \\
\text { employees (30+ } \\
\text { yrs) reported that } \\
\text { HVs used to visit in } \\
\text { late morning, but } \\
\text { at present only 5-6 } \\
\text { birds would come }\end{array}$ & $\begin{array}{l}\text { As HVs } \\
\text { declined, } \\
\text { Marabou } \\
\text { Stork } \\
\text { numbers } \\
\text { increased }\end{array}$ & $\begin{array}{l}\text { Used to see } \\
\text { as many as } \\
30 \mathrm{HVs} \text { at } \\
\text { the site }\end{array}$ & $\begin{array}{l}\text { Occasionally } \\
\text { poisoned dogs } \\
\text { using } \\
\text { Strychnine and } \\
\text { then reportedly } \\
\text { buried the } \\
\text { carcasses. } \\
\text { Many trees had } \\
\text { been felled } \\
\text { around the site } \\
\text { and this may } \\
\text { have } \\
\text { contributed to } \\
\text { their decline }\end{array}$ & $\begin{array}{l}\text { More } \\
\text { common in } \\
\text { dry season }\end{array}$ & $\begin{array}{l}\text { Respondent } \\
\text { directed us to } \\
\text { Bungoma District } \\
\text { Hospital, sewage } \\
\text { works and Kitale } \\
\text { Town to find HVs }\end{array}$ \\
\hline Bungoma & $\begin{array}{l}\text { Hospital } \\
\text { dumpsite }\end{array}$ & Good & 15 & $\begin{array}{l}\text { Feeding on } \\
\text { disposed } \\
\text { flesh prior } \\
\text { to } \\
\text { incineration }\end{array}$ & $\mathrm{n} / \mathrm{a}$ & $\begin{array}{l}\text { Reported as } \\
\text { abundant, feeding } \\
\text { in early morning } \\
\text { and roosting in } \\
\text { trees within the } \\
\text { compound in the } \\
\text { evenings }\end{array}$ & $\begin{array}{l}\text { None } \\
\text { mentioned }\end{array}$ & $\begin{array}{l}\text { None } \\
\text { mentioned }\end{array}$ & $\begin{array}{l}\text { No reports of } \\
\text { vermin } \\
\text { poisoning }\end{array}$ & & \\
\hline
\end{tabular}


Table 2 - continued

\begin{tabular}{|c|c|c|c|c|c|c|c|c|c|c|c|}
\hline Location & $\begin{array}{l}\text { Type of } \\
\text { facility }\end{array}$ & $\begin{array}{l}\text { Quality of } \\
\text { survey }\end{array}$ & $\begin{array}{l}\text { Number of } \\
\text { HVs } \\
\text { observed }\end{array}$ & $\begin{array}{l}\text { Animal } \\
\text { waste } \\
\text { visible }\end{array}$ & $\begin{array}{l}\text { Effluent } \\
\text { disposal } \\
\text { (open/closed) }\end{array}$ & $\begin{array}{l}\text { Status of } \\
\text { HV }\end{array}$ & $\begin{array}{l}\text { Evidence of } \\
\text { competition }\end{array}$ & $\begin{array}{l}\text { Evidence of } \\
\text { decline }\end{array}$ & $\begin{array}{l}\text { Possible reasons } \\
\text { for decline }\end{array}$ & $\begin{array}{l}\text { Evidence of } \\
\text { seasonality }\end{array}$ & Comments \\
\hline Webuye & $\begin{array}{l}\text { Slaughter } \\
\text { house }\end{array}$ & Good & 0 & No & Closed & $\begin{array}{l}\text { Reported as } \\
\text { no longer } \\
\text { observed at } \\
\text { site }\end{array}$ & $\begin{array}{l}\text { None } \\
\text { mentioned }\end{array}$ & $\begin{array}{l}\text { Over } 10 \mathrm{HVs} \\
\text { would come at any } \\
\text { one time, but from } \\
\text { around } 2002 \text { they } \\
\text { stopped coming }\end{array}$ & $\begin{array}{l}\text { Respondent } \\
\text { suspected HVs } \\
\text { died away from } \\
\text { carcasses that } \\
\text { were poisoned by } \\
\text { Town Council vets } \\
\text { to kill rabid dogs. } \\
\text { Dog carcasses } \\
\text { found around } \\
\text { slaughter house } \\
\text { and disposed of in } \\
\text { effluent disposal } \\
\text { pits }\end{array}$ & $\begin{array}{l}\text { More } \\
\text { common in } \\
\text { dry season }\end{array}$ & $\begin{array}{l}\text { Respondent } \\
\text { directed us to } \\
\text { Bungoma, } \\
\text { Kimilili and } \\
\text { Kitale to find } \\
\text { HVs }\end{array}$ \\
\hline Malaba & $\begin{array}{l}\text { Slaughter } \\
\text { house }\end{array}$ & Poor & 0 & No & Closed & $\begin{array}{l}\text { Unknown by } \\
\text { respondents. } \\
\text { Respondents } \\
\text { knew only of } \\
\text { Marabou } \\
\text { Storks from } \\
\text { the facility }\end{array}$ & $\mathrm{n} / \mathrm{a}$ & $\begin{array}{l}\text { Marabou Stork } \\
\text { numbers had } \\
\text { reduced since the } \\
\text { facility was } \\
\text { upgraded to a } \\
\text { closed facility with } \\
\text { underground } \\
\text { disposal pits }\end{array}$ & $\begin{array}{l}\text { No poisoning of } \\
\text { pests at the facility }\end{array}$ & & $\begin{array}{l}\text { Respondent } \\
\text { said HVs could } \\
\text { be seen at } \\
\text { Webuye Town } \\
\text { slaughterhouse }\end{array}$ \\
\hline
\end{tabular}


Table 2 - continued

\begin{tabular}{|c|c|c|c|c|c|c|c|c|c|c|c|}
\hline Location & $\begin{array}{l}\text { Type of } \\
\text { facility }\end{array}$ & $\begin{array}{l}\text { Quality of } \\
\text { survey }\end{array}$ & $\begin{array}{l}\text { Number of } \\
\text { HVs } \\
\text { observed }\end{array}$ & $\begin{array}{l}\text { Animal } \\
\text { waste } \\
\text { visible }\end{array}$ & $\begin{array}{l}\text { Effluent } \\
\text { disposal } \\
\text { (open/closed) }\end{array}$ & Status of HV & $\begin{array}{l}\text { Evidence of } \\
\text { competition }\end{array}$ & $\begin{array}{l}\text { Evidence of } \\
\text { decline }\end{array}$ & $\begin{array}{l}\text { Possible } \\
\text { reasons for } \\
\text { decline }\end{array}$ & $\begin{array}{l}\text { Evidence of } \\
\text { seasonality }\end{array}$ & Comments \\
\hline Malaba & $\begin{array}{l}\text { Sewage } \\
\text { works }\end{array}$ & Poor & 0 & & & & & & & & $\begin{array}{l}\text { Mis-managed and } \\
\text { seemingly non- } \\
\text { operational }\end{array}$ \\
\hline Malaba & Dumpsite & Poor & 0 & & & $\begin{array}{l}\text { No HVs } \\
\text { observed }\end{array}$ & & & & & $\begin{array}{l}\text { Non-organic solid } \\
\text { waste disposal field }\end{array}$ \\
\hline Bungoma & $\begin{array}{l}\text { Sewage } \\
\text { works }\end{array}$ & Poor & 0 & & & & & & & & $\begin{array}{l}\text { Interviewee did not } \\
\text { know of HVs }\end{array}$ \\
\hline Kitale & $\begin{array}{l}\text { Slaughter } \\
\text { house }\end{array}$ & Poor & 0 & No & Closed & $\begin{array}{l}\text { Reported as } \\
\text { having been } \\
\text { seen further } \\
\text { north of Kitale }\end{array}$ & $\begin{array}{l}\text { None } \\
\text { mentioned }\end{array}$ & Unknown & $\begin{array}{l}\text { Unknown, not } \\
\text { aware of any } \\
\text { poisoning } \\
\text { activities }\end{array}$ & & \\
\hline Kakamega & Golf Hotel & Poor & 0 & & & $\begin{array}{l}\text { No HVs } \\
\text { observed and } \\
\text { employees of } \\
\text { Golf Hotel } \\
\text { denied HVs } \\
\text { roosted there }\end{array}$ & & & & & $\begin{array}{l}\text { Interviewees did not } \\
\text { know of HVs, only } \\
\text { knew of Marabou } \\
\text { Storks }\end{array}$ \\
\hline Kakamega & $\begin{array}{l}\text { Slaughter } \\
\text { house }\end{array}$ & Poor & 0 & & & & & & $\begin{array}{l}\text { No evidence of } \\
\text { poisoning }\end{array}$ & & $\begin{array}{l}\text { Directed to Golf Hotel } \\
\text { to find HVs }\end{array}$ \\
\hline
\end{tabular}




\section{Appendix 1}

$\underline{\text { Hooded Vulture questionnaire: facilities }}$

Male/Female: $\quad$ Age:

How long have you worked here?

Do you know this bird (show picture)?

Have you ever seen it around here?

If no, do you know where I can find it?

If yes, what was it doing? (in general, over the times it was observed)

If eating, do you know what (be as precise as possible) it was eating? (in general, over the times it was observed)

Do you still see it here? If not, when was the last time you saw it?

How many birds have you seen at once?

How many birds do you usually see now?

Do you see them every day or during what times of year?

What time do you see them?

Have you ever seen this bird lying dead?

If yes, do you know what happened?

Does the slaughterhouse ever poison animal pests (e.g. rats, dogs or crows)?

If so, do you know what poison they use? And how often?

What animals have been killed by the poison?

What happens to poisoned carcasses, are they buried? 


\section{Appendix 2}

\section{Hooded Vulture questionnaire: fetish}

Male/Female:

Age:

Tribe/community:

What type of animal fetishes do you sell?

Do you sell bird fetishes?

What kinds of birds do you sell?

Do you know this bird (show picture)?

Have you ever known it (or other vulture species) to be used for witchcraft or traditional medicine?

If so, do you sell it now? Why or why not?

What part(s) is used? And what is it used to treat or how is it used?

How much does it cost?

Has the price changed in the last 5 years? Why or why not?

Do you know where the birds were acquired?

Do you know where I can find this bird now?

Is there a demand for vulture parts/bodies? If so, what parts and for what purpose? 